\title{
Characteristics of Use of Geology Literature
}

A citation analysis was made of a selection of the geology literature to determine the characteristics of literature use in current geologic research. More than three-fourths of the citations examined were to serial literature. More than 87 per cent were to literature in the English language. More than one-third were to publications that had appeared during the previous five years. Forty-six titles included half of the journal articles cited. Only 59 per cent of the references were to journals classed by LC in geology; the balance fell in other disciplines.

G EOLOGIC LITERATURE apparently does not become outdated as rapidly as the literature of some other sciences. ${ }^{1} \mathrm{~A}$ dozen years have elapsed since the last major study on the topic, and this span was believed to be sufficient to warrant another analysis of geologic literature.

It has been the purpose of this study to analyze the characteristics of use of the literature of geology. The characteristics were defined by Stevens ${ }^{2}$ and included:

1. The form, whether book, serial, or other, that the literature of geology took.

2. The language distribution of the literature.

3. The time span over which the literature remained useful to researchers.

4. The title distribution which gave an

\footnotetext{
${ }^{1}$ Charles Harvey Brown, Scientific Serials: Characteristics and Lists of Most Cited Publications in Mathematics, Physics, Chemistry, Geology, Physiology, Botany, Zoology, and Entomology. ("ACRL Monograph Number 16," [Chicago: Association of College and Research Libraries, 1956]), p. 106-7.

${ }^{2}$ Rolland E. Stevens, Characteristics of Subject Literatures. ("ACRL Monograph Number 6," [Chicago: Association of College and Research Libraries, 1953]), p. 12-17.
}

Mr. Craig is Librarian of Avon Old Farms, Avon, Connecticut. indication of the number of sources which had to be consulted in order to keep abreast of a subject specialization.

5. The number of different subject areas which contained information useful to a geologist.

There have been three studies in the past similar to the present one. The Gross and Woodford analysis ${ }^{3}$ of 1931 examined six American serials published in 1929. From the study can be determined the form dispersion, temporal span, language dispersion, title distribution, and the subject dispersion of the geologic literature of the period. Both Brown $^{4}$ and LaoSunthara ${ }^{5}$ conducted studies of the serial literature of geology in 1956. Brown analyzed the 1953 and 1954 issues of the journals used as source journals in the Gross and Woodford study. The same dispersions, with the exception of form distribution, were discussed by, or could be gathered from, the Brown study. Brown mentioned

${ }^{3}$ P. L. K. Gross and A. O. Woodford, "Serial Literature Used by American Geologists," Science, LXXIII (June 19, 1931), 660-64.

4 Brown, op. cit., p. 189.

s Maria Eugenia LaoSunthara, "Some Bibliographical Characteristics of Serial Literature in the Field of Geology" (unpublished doctoral dissertation, Indiana University, Bloomington, 1956), 94p. 
form dispersion specifically only insofar as citations to books were concerned. ${ }^{6}$

As the basis of a pilot study, LaoSunthara utilized the 1952 issues of six of the journals Gross and Woodford found to be most important in their analysis. The pilot study served to determine the source journals for the main investigation. The characteristics analyzed in the present study were covered by LaoSunthara.

The data for this study were obtained from ten source journals which were chosen by requesting that a selected group of librarians in charge of geologic collections from all parts of the United States rank geologic serials in the order of importance to their libraries. The 1960 and 1965 issues of the source journals were studied. The source journals were: Geological Society of America; Bulletin, Journal of Geology, American Association of Petroleum Geologists; Bulletin, American Journal of Science, U.S. Geological Survey; Bulletin, U.S. Geological Survey; Professional Paper, Economic Geology, American Mineralogist; Journal of Geophysical Research; Journal of Paleontology.

Citation counting was used, and for each citation was recorded its subject area, title, language, form, and its date. It was decided that only a sample of the total population was necessary in order to analyze the literature, and through the use of a statistical formula found in Yamane ${ }^{7}$ the necessary sample size was determined. The formula was $\mathrm{n}=\frac{\mathrm{N}}{1+\mathrm{Ne}^{2}}$ where $\mathrm{n}=$ the size of the sample, $\mathrm{N}=$ the total population, $\mathrm{e}=$ the error in per cent. The sample size for both 1960 and 1965 was increased to four hundred to facilitate later computations. After finding the sample size, the most straightforward method of obtaining a

\footnotetext{
Brown, op. cit., p. 106.

Taro Yamane, Statistics; an Introductory Analysis, 2d ed. (New York: Harper and Row, 1967), p. 57981.
}

distribution sample from population, according to Wert, ${ }^{8}$ consists of choosing the individual cases by unrestricted random sampling, with the aid of a table of random numbers, an easily applied device for selecting a random sample from population, each number of which can be identified and numbered. The table of random numbers used in this study was The Rand Corporation's A Million Random Digits. ${ }^{9}$

The findings of this analysis show that:

1. Serial literature was the most important form of literature used by geologists. In $1965,75.5$ per cent of the citations were to periodicals, with 21.5 per cent to books, and the balance, 3 per cent, divided between maps, theses, and other unpublished papers. Table 1 is an analysis of the form dispersion for 1960 and 1965.

2. The language distribution of geologic literature was low when compared to that of some other subject literatures. ${ }^{10}$ Eighty-seven and one half per cent of the citations were to materials published in English in 1965. German was the most frequently used foreign language, followed by French and Dutch. Table 2 indicates the language dispersion for 1960 and 1965 .

3 . In 1965 , the temporal distribution of the literature was high. It was determined that the geologist involved in research would have to go back fifteen years to search about 70 per cent of the useful literature, and about twentyfive years to search about 80 per cent of the literature. An analysis of the temporal dispersion is found in Table 3.

4. The title dispersion for the litera-

\footnotetext{
${ }^{8}$ James E. Wert, Charles O. Neidt, and J. Stanley Ahmann, Statistical Methods in Educational and Psychological Research (New York: Appleton-CenturyCrofts, Inc., 1954), p. 108-109.

The Rand Corporation, A Million Random Digits with 100,000 Normal Deviates (Glencoe, Illinois: The Free Press, 1955), 400 and 200 p.

${ }_{10}$ The various dispersions of other subjects literature may be found in Stevens' Characteristics of Subject Literatures.
} 
TABLE 1

Form Dispersion of Geologic Literature

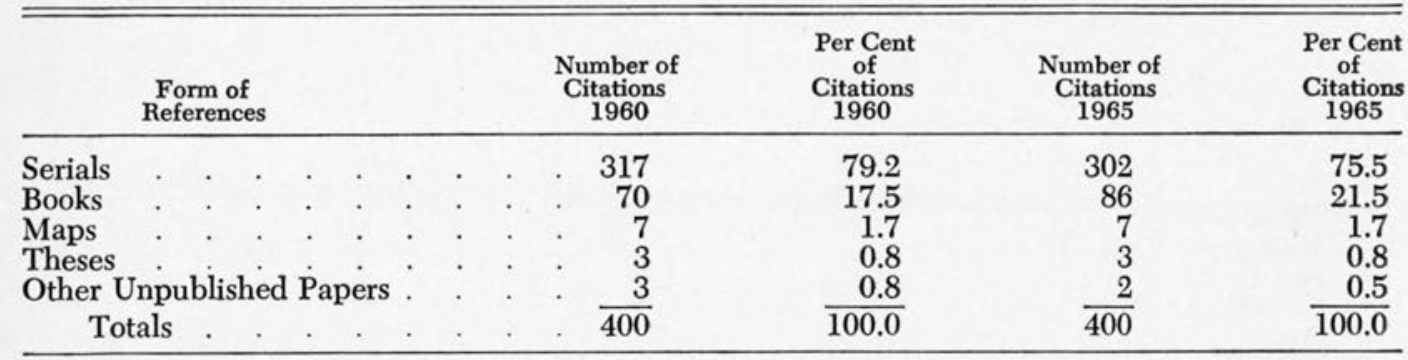

TABLE 2

Language Dispersion of Geologic Literature

\begin{tabular}{|c|c|c|c|c|c|c|c|c|c|c|}
\hline $\begin{array}{c}\text { Language } \\
\text { of } \\
\text { Material } \\
\text { Cited }\end{array}$ & & & & & & & $\begin{array}{c}\text { Number of } \\
\text { Citations } \\
1960\end{array}$ & $\begin{array}{c}\text { Per Cent } \\
\text { of } \\
\text { Citations } \\
1960\end{array}$ & $\begin{array}{l}\text { Number of } \\
\text { Citations } \\
1965\end{array}$ & $\begin{array}{l}\text { Per Cent } \\
\text { of } \\
\text { Citations } \\
1965\end{array}$ \\
\hline English . & & & . & & & . & . 349 & 87.3 & 350 & 87.5 \\
\hline German . & . & . & . & . & . & . & 6 & 1.5 & 15 & 3.8 \\
\hline French : & & . & . & . & . & . & 13 & 3.2 & 10 & 2.5 \\
\hline Dutch . & . & . & . & . & . & . & 2 & 0.5 & 10 & 2.5 \\
\hline Italian & . & . & . & . & . & . & $\overline{4}$ & 1.0 & - & - \\
\hline Japanese & . & . & . & . & . & & 7 & 1.8 & 3 & 0.8 \\
\hline Norwegian & 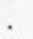 & . & . & . & . & . & 3 & 0.8 & - & - \\
\hline Russian . & & & . & . & . & . & 5 & 1.2 & 3 & 0.8 \\
\hline Czechoslovak & & . & . & . & . & . & - & - & 2 & 0.5 \\
\hline Swedish. & 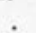 & . & . & . & & . & 3 & 0.8 & 2 & 0.5 \\
\hline Austrian. & . & . & . & . & . & . & - & - & $\overline{1}$ & 0.3 \\
\hline Belgian. & . & . & . & . & . & . & - & - & 1 & 0.2 \\
\hline Danish & . & . & . & . & . & . & 3 & 0.8 & 1 & 0.2 \\
\hline Greenlandic & & . & . & . & . & & - & - & $\hat{1}$ & 0.2 \\
\hline Spanish & . & $\therefore$ & : & . & . & : & 2 & 0.5 & 1 & 0.2 \\
\hline Brazilian & & . & . & . & . & . & 1 & 0.2 & - & - \\
\hline Finnish & . & . & . & . & . & : & 1 & 0.2 & - & - \\
\hline Icelandic & $\therefore$ & . & : & . & . & : & 1 & 0.2 & - & - \\
\hline Totals & . & . & . & . & . & . & $\overline{400}$ & $\overline{100.0}$ & $\overline{400}$ & $\overline{100.0}$ \\
\hline
\end{tabular}

TABLE 3

Temporal Dispersion of Geologic Literature

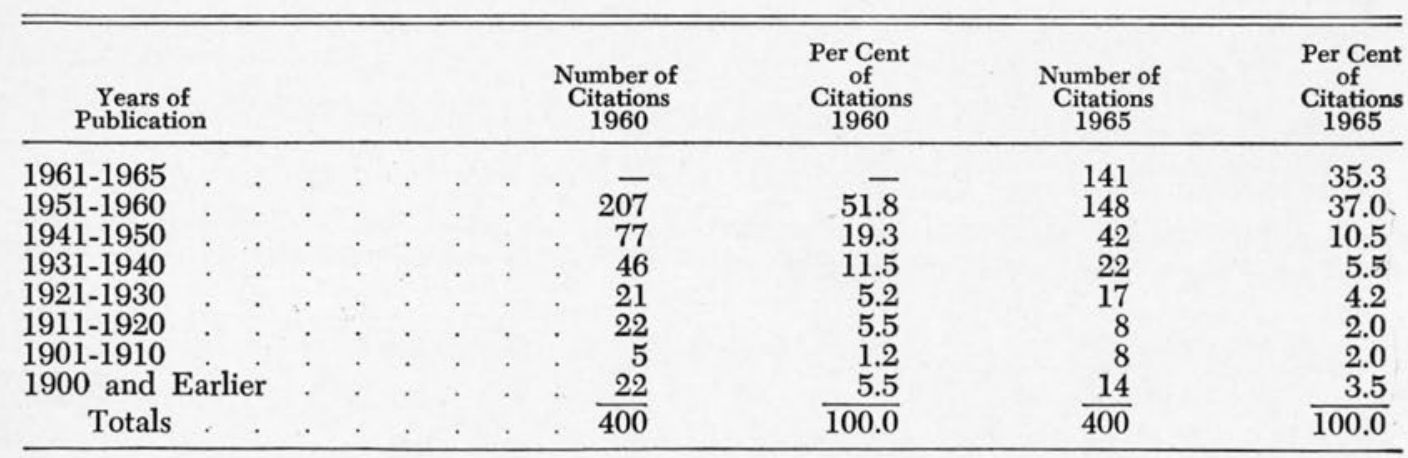


TABLE 4

TITLE DisPERSION FOR 1960

\begin{tabular}{|c|c|c|c|c|}
\hline Rank & Title & $\begin{array}{l}\text { Number of } \\
\text { Citations }\end{array}$ & $\begin{array}{c}\text { Per Cent } \\
\text { of Citations }\end{array}$ & $\begin{array}{l}\text { Cumulative } \\
\text { Per Cent } \\
\text { of Citations }\end{array}$ \\
\hline 1 & Geological Society of America. Bulletin & 28 & 7.00 & \\
\hline $\begin{array}{l}2 \\
3\end{array}$ & $\begin{array}{l}\text { U.S. Geological Survey. Bulletin } \\
\text { U.S. Geological Survey, Professional }\end{array}$ & 17 & 4.25 & 11.25 \\
\hline & Paper. & 15 & 3.75 & 15.00 \\
\hline 4 & Economic Geology & 11 & 2.75 & 17.75 \\
\hline 5 & American Association of Petroleum & & & \\
\hline & Geologists. Bulletin & 9 & 2.25 & 20.00 \\
\hline $\begin{array}{l}6 \\
6\end{array}$ & American Journal of Science & $\begin{array}{l}8 \\
8\end{array}$ & 2.00 & 22.00 \\
\hline $\begin{array}{l}6 \\
8\end{array}$ & Journal of Geology & 8 & $\begin{array}{l}2.00 \\
1.50\end{array}$ & 24.00 \\
\hline$\stackrel{8}{9}$ & $\begin{array}{l}\text { Journal of Paleontology } \\
\text { Journal of Geophysical Research }\end{array}$ & 5 & 1.25 & $\begin{array}{l}25.50 \\
26.75\end{array}$ \\
\hline 10 & American Mineralogist & 4. & 1.00 & $\begin{array}{l}26.75 \\
27.75\end{array}$ \\
\hline 10 & Gulf Coast Association of Geological & & & \\
\hline & Societies Transactions . & 4 & 1.00 & 28.75 \\
\hline 10 & Mineralogical Magazine & 4 & 1.00 & 29.75 \\
\hline 10 & Nature & 4 & 1.00 & 30.75 \\
\hline 10 & $\begin{array}{l}\text { Royal Astronomical Society. Monthly } \\
\text { Notices, Geophysical Supplements }\end{array}$ & 4 & 1.00 & \\
\hline 10 & $\begin{array}{l}\text { Notices, Geophysical Supplements } \\
\text { Royal Society of London. Proceedings }\end{array}$ & 4 & 1.00 & 32.75 \\
\hline 10 & Science & 4 & 1.00 & 33.75 \\
\hline 17 & Akademiia Nauk SSSR. Doklady : . & 3 & 0.75 & 34.50 \\
\hline 17 & Canada. Geological Survey. Memoirs . & 3 & 0.75 & 35.25 \\
\hline & $\begin{array}{l}\text { Canada. Geological Survey. } \\
\text { Summary Report }\end{array}$ & 3 & & 36.00 \\
\hline 17 & Geological Society of America. & 0 & 0.15 & 36.00 \\
\hline 17 & $\begin{array}{l}\text { Special Paper } \\
\text { Institute of Radio Engineers. }\end{array}$ & 3 & 0.75 & 36.75 \\
\hline & Proceedings & 3 & 0.75 & 37.50 \\
\hline 17 & U.S. Bureau of Mines. & & & \\
\hline 23 & $\begin{array}{l}\text { Report of Investigations } \\
\text { Academy of Natural Sciences of }\end{array}$ & 3 & 0.75 & 38.25 \\
\hline & Philadelphia. Proceedings & 2 & 0.50 & 38.75 \\
\hline $\begin{array}{l}23 \\
23\end{array}$ & American Chemical Society. Journal . & 2 & 0.50 & 39.25 \\
\hline 23 & $\begin{array}{l}\text { American Meteorological Society. } \\
\text { Bulletin }\end{array}$ & & & \\
\hline 23 & $\begin{array}{l}\text { Bulletin } \\
\text { Arkiv for Mineralogi och Geologi }\end{array}$ & $\begin{array}{l}2 \\
2\end{array}$ & $\begin{array}{l}0.50 \\
0.50\end{array}$ & 39.75 \\
\hline 23 & California. University. Department of & & 0.50 & 40.25 \\
\hline & Geological Sciences. Bulletin & 2 & 0.50 & 40.75 \\
\hline 23 & Discovery Reports & 2 & 0.50 & 41.25 \\
\hline 23 & Eclogae Geologicae Helvetiae & 2 & 0.50 & 41.75 \\
\hline $\begin{array}{l}23 \\
23\end{array}$ & $\begin{array}{l}\text { Geochimica et Cosmochimica Acta } \\
\text { Geological Society of America. }\end{array}$ & 2 & 0.50 & 42.25 \\
\hline & Memoirs & 2 & 0.50 & 42.75 \\
\hline 23 & Geological Society of London. & & & \\
\hline 23 & $\begin{array}{l}\text { Quarterly Journal } \\
\text { Harvard University. Museum }\end{array}$ & 2 & 0.50 & 43.25 \\
\hline & of Comparative Zoology. Bulletin & 2 & 0.50 & 43.75 \\
\hline $\begin{array}{l}23 \\
23\end{array}$ & Japan. Geological Survey. Bulletin & 2 & 0.50 & 44.25 \\
\hline 23 & $\begin{array}{l}\text { Journal of Atmospheric } \\
\text { and Terrestrial Physics . }\end{array}$ & 2 & 0.50 & 44.75 \\
\hline 23 & Journal of Geomagnetism & & & \\
\hline 23 & $\begin{array}{l}\text { and Geoelectricity } \\
\text { Neues Jahrbuch fur Mineralogie, }\end{array}$ & 2 & 0.50 & 45.25 \\
\hline & Geologie und Palaontologie & 2 & 0.50 & 45.75 \\
\hline & New York. State Museum. Bullettn & 2 & 0.50 & 46.25 \\
\hline 23 & Physical Review & 2 & 0.50 & 46.75 \\
\hline 23 & $\begin{array}{l}\text { Royal Society of London. } \\
\text { Philosophical Transactions }\end{array}$ & & & \\
\hline 23 & $\begin{array}{l}\text { Philosophical Transactions } \\
\text { Societe Geologique de France. Bulletin }\end{array}$ & $\begin{array}{l}2 \\
2\end{array}$ & $\begin{array}{l}0.50 \\
0.50\end{array}$ & $\begin{array}{l}47.25 \\
47.75\end{array}$ \\
\hline 23 & $\begin{array}{l}\text { Societe Geologique de } \\
\text { France. Memoires }\end{array}$ & 2 & 0.50 & \\
\hline & cee. Memoires & & & 48.25 \\
\hline
\end{tabular}




\begin{tabular}{|c|c|c|c|c|}
\hline Rank & Title & $\begin{array}{l}\text { Number of } \\
\text { Citations }\end{array}$ & $\begin{array}{l}\text { Per Cent } \\
\text { of Citations }\end{array}$ & $\begin{array}{l}\text { Cumulative } \\
\text { Per Cent } \\
\text { of Citations }\end{array}$ \\
\hline \multirow{3}{*}{$\begin{array}{l}23 \\
23\end{array}$} & $\begin{array}{l}\text { U.S. Geological Survey. } \\
\text { Annual Report }\end{array}$ & 2 & 0.50 & 48.75 \\
\hline & U.S. National Bureau of & & & \\
\hline & Standards. Journal of Research & 2 & 0.50 & 49.25 \\
\hline 23 & $\begin{array}{l}\text { M.S. Weather Bureau. } \\
\text { Monthly Weather Review . }\end{array}$ & 2 & 0.50 & 49.75 \\
\hline 23 & $\begin{array}{l}\text { Washington Academy of } \\
\text { Sciences }\end{array}$ & ? & 0.50 & \\
\hline 47 & $\begin{array}{l}\text { One hundred ninety-nine titles with } \\
\text { one citation each: } 116 \text { serials, } 70 \text { books, } \\
7 \text { maps, } 3 \text { theses, } 3 \text { other unpublished }\end{array}$ & 2 & & 50.25 \\
\hline & papers & 199 & 49.75 & 100.0 \\
\hline
\end{tabular}

ture was high. In 1960, the first fortysix journals accounted for just over 50 per cent of the literature, and in order to cover 75 per cent of the literature, one had to search 145 titles. Table 4 indicates the title dispersion for 1960. In 1965 , the first thirty-seven serials accounted for 50 per cent of the literature, and in order to cover 75 per cent of the literature, one had to search 127 titles. Table 5 indicates the title dispersion for 1965 .

The subject distribution of geologic literature was also high. Subjects other than geology accounted for 43 per cent of the literature used by research geologists in 1960 and 40.8 per cent in 1965. Table 6 is an analysis of the subject dispersion.

The findings of this study have several implications for libraries which either have geologic research collections or are contemplating such collections. Tables 4 and 5 , which indicate the title dispersions for 1960 and 1965, may serve as guides to determine which titles to obtain on first purchase. In addition, since these titles have been the most useful to research workers in geology, the tables may offer help in determining which serials to bind for future reference.

Since it was found that serials were the most common form of literature used, a library may decide to allocate the majority of its budget for the pur- chase of periodicals and divide the balance among the other useful forms of literature.

Because of the dependence upon literature in subject areas other than geology, librarians in charge of geologic collections in a departmentalized university library may work cooperatively with other departments to avoid purchase duplications. In a centralized collection, the geologic researcher will be best served by locating other useful subject areas such as physics and mining engineering near the geologic collection. Librarians in charge of specialized geologic collections must also be aware of these other subject areas so as to be able to provide researchers with the necessary material either through purchase or interlibrary loan.

In hiring personnel, a lack of a language proficiency would seem to be no great barrier to employment, although a working knowledge of French or German would prove helpful.

The temporal distribution may serve as a guide to librarians, indicating to them the degree to which useful information is found in the geologic literature of the past, and should, therefore, be kept in the collection. The temporal dispersion may also serve as a guide to librarians desiring to purchase backfiles of periodicals by indicating how far back in time to purchase. 
TABLE 5

Trtle Dispersion for 1965

\begin{tabular}{|c|c|c|c|c|}
\hline Rank & Title & $\begin{array}{l}\text { Number of } \\
\text { Citations }\end{array}$ & $\begin{array}{c}\text { Per Cent } \\
\text { of Citations }\end{array}$ & $\begin{array}{l}\text { Cumulative } \\
\text { Per Cent } \\
\text { of Citations }\end{array}$ \\
\hline 1 & Geological Society of America. Bulletin & 29 & 7.25 & \\
\hline 2 & Journal of Geophysical Research & 23 & 5.75 & 13.00 \\
\hline 3 & Economic Geology & 15 & & 16.75 \\
\hline \multirow[t]{2}{*}{4} & American Association of Petroleum & & & \\
\hline & Geologists. Bulletin . & 12 & 3.00 & 19.75 \\
\hline 5 & U.S. Geological Survey. Bulletin & 10 & 2.50 & 22.25 \\
\hline 5 & U.S. Geological Survey. Professional Pape & 10 & 2.50 & 24.75 \\
\hline 7 & Science & 9 & 2.25 & 27.00 \\
\hline 8 & Journal of Paleontology & 8 & 2.00 & 29.00 \\
\hline 9 & American Mineralogist & 6 & 1.50 & 30.50 \\
\hline 9 & Geochimica et Cosmochimica Acta & 6 & 1.50 & 32.00 \\
\hline 11 & Geological Society of America. Memoirs & 5 & 1.25 & 33.25 \\
\hline 12 & American Journal of Science & 4 & 1.00 & 34.25 \\
\hline 12 & Journal of Geology & 4 & 1.00 & 35.25 \\
\hline 12 & Journal of Sedimentary Petrology & 4 & 1.00 & 36.25 \\
\hline 12 & Nature & 4 & 1.00 & 37.25 \\
\hline 12 & Physical Review & 4 & 1.00 & 38.25 \\
\hline 17 & Acta Crystallographica & 3 & 0.75 & 39.00 \\
\hline 17 & Mineralogical Magazine . & 3 & 0.75 & 39.75 \\
\hline 17 & Ohio. Geological Survey. Bulletin & 3 & 0.75 & 40.50 \\
\hline \multirow{3}{*}{17} & Seismological Society of America. Bulletin & 3 & 0.75 & 41.25 \\
\hline & U.S. Geological Survey. Water- & & & \\
\hline & Supply Paper & 3 & 0.75 & 42.00 \\
\hline 22 & Academy of Natural Sciences of & & & \\
\hline \multirow{2}{*}{22} & $\begin{array}{l}\text { Philadelphia. Proceedings } \\
\text { Akademiia Nauk SSSR. Izvestiva Seriva }\end{array}$ & 2 & 0.50 & 42.50 \\
\hline & $\begin{array}{l}\text { Akademiia Nauk SSSR. Izvestiya. Seriya } \\
\text { Geofizicheskaya }\end{array}$ & 2 & 0.50 & 43.00 \\
\hline 22 & American Geophysical Union. Transaction & 2 & 0.50 & 43.50 \\
\hline 22 & Bulletins of American Paleontology & $\overline{2}$ & 0.50 & 44.00 \\
\hline 22 & Canada. Geological Survey. Memoirs & 2 & 0.50 & 44.50 \\
\hline 22 & Colorado Scientific Society. Proceedings & 2 & 0.50 & 45.00 \\
\hline 22 & Eclogae Geologicae Helvetiae & $\overline{2}$ & 0.50 & 45.50 \\
\hline \multirow{2}{*}{22} & Geological Society of America. Special & & & \\
\hline & Paper : & 2 & 0.50 & 46.00 \\
\hline 22 & Geologische Rundschau & 2 & 0.50 & 46.50 \\
\hline 22 & Geophysical Journal . & 2 & 0.50 & 47.00 \\
\hline 22 & Geophysics. & 2 & 0.50 & 47.50 \\
\hline 22 & Georgia. Geological Survey. Bulletin & 2 & 0.50 & 48.00 \\
\hline 22 & Icarus & 2 & 0.50 & 48.50 \\
\hline 22 & India. Geological Survey. Memoirs & 2 & 0.50 & 49.00 \\
\hline & Indian Botanical Society. Journal & 2 & 0.50 & 49.50 \\
\hline \multirow{2}{*}{$\begin{array}{l}22 \\
22\end{array}$} & Journal of Applied Physics & 2 & 0.50 & 50.00 \\
\hline & Journal of Atmospheric and Terrestrial & & 050 & 50.50 \\
\hline 22 & Journal of Chemical Physics & 2 & 0.50 & 51.00 \\
\hline 22 & Physical Review Letters & 2 & 0.50 & 51.50 \\
\hline 22 & Physical Society of London. Proceedings & 2 & 0.50 & 52.00 \\
\hline 22 & Philosophical Magazine & 2 & 0.50 & 52.50 \\
\hline 22 & Planetary and Space Science & 2 & 0.50 & 53.00 \\
\hline 22 & Scientific American & 2 & 0.50 & 53.50 \\
\hline 22 & Societe Geologique de France. Bulletin & 2 & 0.50 & 54.00 \\
\hline 22 & . & 2 & 0.50 & 54.50 \\
\hline 22 & Space Research & 2 & 0.50 & 55.00 \\
\hline & $\begin{array}{l}\text { One hundred eighty titles with one } \\
\text { citation each: } 82 \text { periodicals, } 86 \text { books, }\end{array}$ & & & \\
\hline & $\begin{array}{l}7 \text { maps, } 3 \text { theses, } 2 \text { other unpublished } \\
\text { papers }\end{array}$ & 180 & 45.00 & 100.00 \\
\hline
\end{tabular}


TABLE 6

Subject Distribution of Geologic Literature

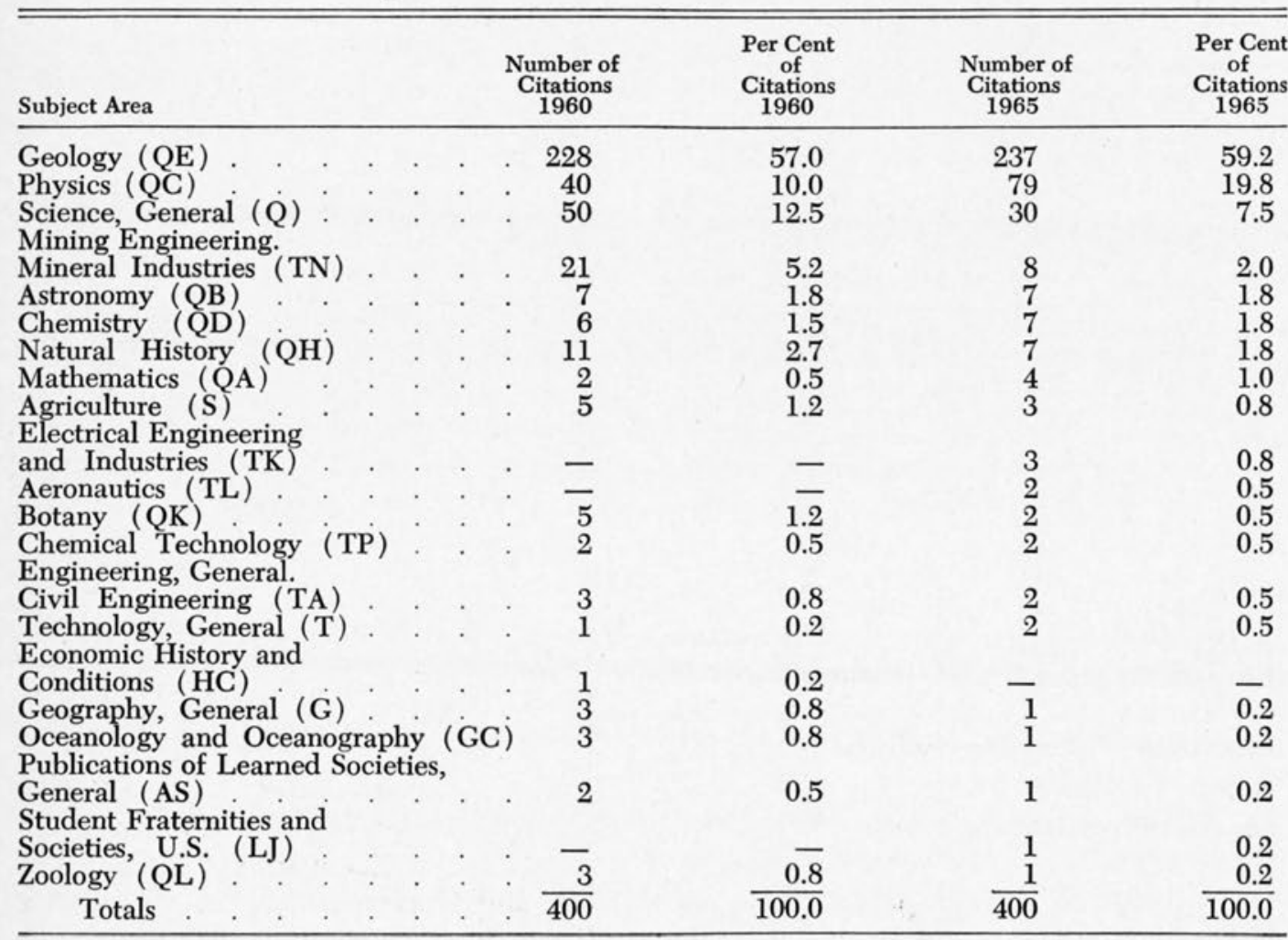

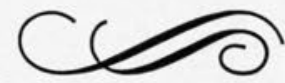

